\title{
Policies and Strategies to Combat Poverty and to Promote Development in Mozambique: Elements of Continuity and Discontinuity
}

\author{
Jochua Abrão Baloi \\ Faculty of Ethics, Human and Legal Sciences of the University of Saint Thomas of Mozambique, Maputo, Mozambique
}

\section{Email address:}

jbaloi@yahoo.com.br

\section{To cite this article:}

Jochua Abrão Baloi. Policies and Strategies to Combat Poverty and to Promote Development in Mozambique: Elements of Continuity and Discontinuity. Journal of Public Policy and Administration. Vol. 3, No. 1, 2019, pp. 19-28. doi: 10.11648/j.jppa.20190301.13

Received: February 13, 2019; Accepted: March 21, 2019; Published: April 13, 2019

\begin{abstract}
This article comes about with the objective of analyzing in a comparative way the elements of continuity and discontinuity between the policies and strategies to combat poverty and to promote development related to the foreign policy that Mozambique adopted after independence. The main idea is that these policies (PPI, PRE (S), PARPA's) did not achieve their goals; so much that they were updated successively, adjusting them according to the political-economic situation in which Mozambique was living. Mozambique pursued this path because it aimed to maintain the defense of the country's independence and sovereignty, eradicating poverty, consolidating national unity and strengthening democracy and freedom. Therefore, it is concluded that in these policies and strategies there is, on the one hand, a continuity of the objectives previously outlined, but also as the intention to better eradicate poverty and achieve development, there are elements of rupture among them.
\end{abstract}

Keywords: Poverty, Development, Politics, Mozambique

\section{Introduction}

This article sets out the comparative analysis of the different policies and strategies to combat poverty and to promote development that have been successively adopted in Mozambique since the time of independence (1975), to the present day, especially in the area of Foreign Policy.

It was in 2010 that the government approved Mozambique's Foreign Policy, a programmatic instrument aimed to achieve the objectives defined for national interests according to the prevailing internal and international environment.

The mission of this policy is to implement proactive diplomatic action to contribute to the consolidation of peace and stability, as well as to eradicate poverty, promote democracy and human rights and, indeed, foster sustainable development in the country, the continent and in the world.

According to the documents recommended in Public Policy matters, this is the case of PRE (Economic Rehabilitation Program), PPI (Indicative Prospective Plan), PARPA (s) (Action Plan (s) for the Reduction of Absolute
Poverty) and PARP (Action Plan (s) for the Reduction of Poverty), the foreign policy issue is very fundamental to understand how Mozambique has advanced within its strategies in order to reduce its external debt to where the country is today. However, this policy has, among several objectives, to guarantee stability and security as well as territorial integrity, economic and social development of the country.

The other document approved by the government is Agenda 2030, which in its summary adds 17 objectives of sustainable development, and which is in part a continuity of the programmatic documents for poverty reduction, as we will mention below and that were built on the aegis of the Millennium Development Goals, particularly on the goals not reached by those documents, but also on their achievements.

In accordance with Agenda 2030, "Mozambique is a member of the United Nations and has participated actively in the processes of elaboration of Universal Development Agendas, such as the 2000-2015 Millennium Declaration, the Addis Ababa Agenda for Action and, more recently, the Agenda 2030 for Sustainable Development. On Agenda 
2030, it should be noted that the United Nations has undertaken an unprecedented comprehensive, participatory and inclusive consultation process. Mozambique was part of this process as one of the 53 countries selected to hold national consultations to define the priorities of this Agenda [1].

One of the objectives that is similar to those announced by the development promotion documents is: to end poverty in all its forms, in all places. The general idea of this goal is that, by 2030, Mozambique must eradicate extreme poverty for all people everywhere, currently measured as people living on less than USD 1.25 per day. Therefore, the proportion of men, women and children of all ages living in poverty in all its dimensions must be halved, according to national definitions [1].

In Mozambique, this study is important from the academic point of view, since the essence of these strategic plans takes all areas of development as the main ones, in the sense that they are essential for poverty reduction and for the country's economic growth, and also because they have profound and comprehensive effects on the consolidation of democracy and peace. The other factor that makes this study relevant is the fact that these priority areas result from a diagnosis of the determinants of poverty in Mozambique, from studies aimed to reduce poverty in Mozambique, and from consultations with civil society and the private sector.

In addition, the results of this article are essential in redefining plans for Mozambique's prosperity, and the results that emerge from it may be useful in the elaboration and / or planning of government achievements in order to improve the situation not only economic and against poverty, as well as that linked to Mozambique's foreign policy.

It is for these factors that all the strategic plans for poverty reduction in Mozambique are based mainly on six pillars that the government proposes to be priorities for the promotion of human development and effectively for the creation of a pleasant environment for the rapid growth of Mozambique, comprehensive and inclusive. For these strategic plans, priority areas are: Education, Health, Agriculture and Rural Development, Basic Infrastructure, Good Governance, Macroeconomic and Financial Management.

Strengthening relations of friendship and cooperation with all members of the international community and contributing to the strengthening of international peace and security, the harmonious progress and well-being of humankind are other objectives advocated in Mozambique's foreign policy.

It is for these factors that it is generally intended to analyze the various policies and strategies to combat poverty in Mozambique, looking for the elements of continuity and discontinuity. Specifically, it is hoped to explore the antipoverty documents (PRE, PPI, PARPA's); to base the guiding aspects of these documents, and finally to assess in them the foreign policy issue that Mozambique adopted.

Another key document is the Government's Five Year Program (2015 to 2019). Generally, each government that takes on governance after the elections has a five-year plan, that is, a set of priorities that the government must carry out.
For the current mandate, the Mozambican government has proposed its central focus on increasing employment, productivity and competitiveness to improve the living conditions of Mozambicans in the countryside and in the city, in an environment of peace, harmony and tranquility, consolidating democracy and participatory and inclusive governance.

In this regard, throughout this period, in accordance with the government's five-year program, the government action will focus on five priorities, such as: consolidating national unity, peace and sovereignty; develop human and social capital; promoting employment, productivity and competitiveness; develop economic and social infrastructures; and ensure sustainable and transparent management of natural resources and the environment [2].

The main issue that guides this article is: to what extent do the different policies and strategies for poverty reduction and development promotion that have been successively adopted in Mozambique since the time of independence contribute to the eradication of poverty? It is based on the assumption that the different policies and strategies for combating poverty and promoting development that have been successively adopted in Mozambique since the time of independence complement each other, allowing the development of Mozambique.

The methodological construction that guides this article involves a symbiosis of several methods (Qualitative, Monographic, Historical, Bibliographic), allying them to the hermeneutic-reflective one for the effective reach of the theoretical and historical reference of the policies and strategies of fight against poverty in Mozambique, so as to make a comparison for the reach of the elements of continuity and discontinuity between them.

This work is divided in three parts, besides the introduction and conclusion. In the first one, the analysis of the different planning instruments in Mozambique in the field of foreign policy is presented in a reasoned way; then is discussed the common problems with the economic options in Mozambique, and finally is presented the external economic relations of Mozambique with the world.

\section{Analysis of the Different Planning Instruments in Mozambique in the Field of Foreign Policy}

\subsection{Indicative Prospective Plan (PPI)}

The PPI is an instrument at the base of which the Mozambican State intended to organize its resources for the development of the agricultural and industrial potential, for the progressive elevation of the standard of living of the people and for the strengthening of the defensive capacity of a socialist homeland [3]

The political system at the time greatly influenced political decisions, since in conceiving this Plan for 10 years (19801990), it sought to find instruments that could rebuild the 
development and economy of the civil war torn country between 1977 and 1992 [4].

It is for these factors that this plan was developed within the guidelines of the III Frelimo1 Congress held in 1977, in order to reinforce the signs that appeared in the recovering economy [4]. Therefore, it was the country's goal to celebrate the victories over underdevelopment in order to build the country, since the President of the Republic, Samora Machel, declared the 1980s an era of struggle against underdevelopment and proclaimed the political campaigns and organizations. From a political-ideological point of view, this campaign advocated the construction of a new state and this is the element that justifies the government's choice of these planning instruments [5].

In the context of the establishment of a dynamic of economic and social development in the period between 1975 and 1980, it was observed that the sanctions applied by Mozambique to Southern Rhodesia (now Zimbabwe) have the consequence of reducing international traffic to the interland countries in the southern African region, which had implications for diplomatic relations between the two countries in the context of bilateral cooperation [6].

In this period, the constant aggression of the minority and racist regime of Southern Rhodesia required the mobilization and channeling of resources to ensure the defense of Mozambican territorial sovereignty and integrity and to ensure support for the constant development of the struggle of the Zimbabwean people for their freedom and national independence [6].

For the first five years, the essence of the economic structure created by colonialism has remained, and it translates into a strong dependence on the outside world for liquid fuels, metals, chemicals, equipment, and spare parts.

The situation has further deteriorated because of new external factors, especially with regard to international market prices. The crisis of capitalist world system had negative effects on the development process, which translated into the deterioration of the terms of trade.

Therefore, with the conception of the PPI, the Mozambican economy was oriented in accordance with the central axes defined by the socialization of the countryside and agrarian development, which was based on two elements: on the one hand, the accelerated development of the agrarian state sector in agricultural exploration and mechanization, carried out mainly through large projects that responded to the needs of the people and made the state sector dominant in the national economy); on the other, in the cooperativity of the countryside - the transformation of millions of peasants into a strong socialist peasantry built under new relations of production [7].

1Liberation Front of Mozambique, which is the party in power, was founded in 1962 in Tanzania by Eduardo Mondlane, as a revolutionary movement. This revolutionary movement united several movements of nationalist character and led the struggle of liberation of Mozambique, against the Portuguese colonialism. With the proclamation of National Independence on June 25, 1975, he led the leadership of the transitional government and subsequent governments, becoming a political party in 1977 .
The table and chart below shows the evolution of global social production at constant 1980 prices, that is, the effects of the PPI in this period, which, above all, shows a high economic growth of about $5 \%$.

Table 1. Evolution of global social production (1980 constant prices), 1975 to 1986.

\begin{tabular}{|c|c|c|c|c|c|c|}
\hline & 1975 & 1977 & 1980 & 1982 & 1984 & 1986 \\
\hline $\begin{array}{l}\text { Global Social } \\
\text { Production (GSP) }\end{array}$ & 71.1 & 75 & 82.1 & 78,8 & 58,2 & 56,2 \\
\hline Agricultural GSP (\%) & - & - & 37,5 & 39,1 & 41,9 & 48,7 \\
\hline $\begin{array}{l}\text { Real growth rate, base } \\
1980\end{array}$ & - & 5.6 & 4,4 & $-6,3$ & $-9,6$ & 4,3 \\
\hline $\begin{array}{l}\text { Annual consumer } \\
\text { price index }\end{array}$ & - & 1 & 2 & 17,6 & 30,3 & 16,9 \\
\hline
\end{tabular}

Source: Mosca (2005) quoted for the years 1975 and 1977, CNP (1985), Statistical Information, 1975-1984. Ministry of Agriculture (1987).

In this sense, during this period, most of the economic indicators had positive behavior, since the inflation rate of the official market was controlled (between 1 and 2 percent); public accounts remained balanced; contrary to public consumption, private consumption has increased; exports grew (although imports grew faster); production has increased in almost all sectors [8].

The dizzying rise in import prices of the capitalist world has nullified domestic production efforts triggered by the state. The main way to reverse this scenario was to maximize exports and minimize imports to counter the imbalance in the Mozambican trade balance.

Thus, the import structure of Mozambique at that time clearly expressed the strong dependence of the national economy on the import of crude oil and its by-products, raw materials, parts and spare parts to increase the pace of production growth [8].

However, the PPI for the decade 1981-1990, which was the guide for state action, was a fundamental instrument for the construction of a relatively developed socialist economy [8]. This argument expresses a deep relationship between Mozambique and the socialist countries in the context of bilateral cooperation at the time, in addition to allowing rapid international cooperation aimed to development, based on the maximization of production for the export and import of semi-finished products whose completion would take place in soil Mozambican government.

"Industrialization was defined as a very important element as a factor for the dynamization of agriculture" [9]. And according to the PPI, at the political level, "industrialization has contributed to the country's liberation from dependence to the outside, creating conditions for the permanent strengthening of defensive capacity, as well as enlarging and strengthening the proletariat" [10].

Therefore, the PPI defines as a fundamental task, the creation of a national transport system for the disposal of production taking into account the geographical location of the country and the distribution of its economic activities. This means that the basis was the establishment of new production, commercialization, export and construction scales, with the guarantee of international iron-port traffic [10]. 


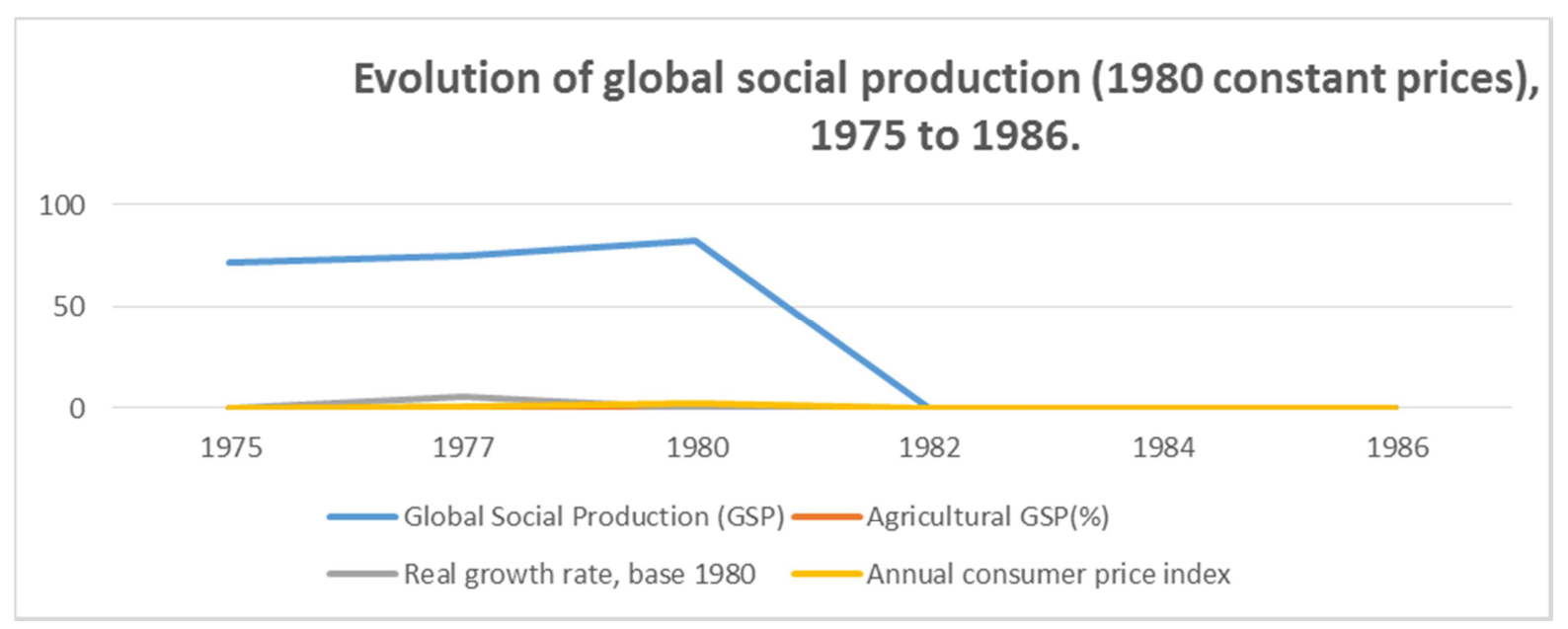

Figure 1. Evolution of global social production (1980 constant prices), 1975 to 1986.

The academic training abroad also marked the Foreign Policy, that is, the cooperation relations between Mozambique and other countries, as well as international institutions. That is why "to comply with the Economic and Social Directives (1983) after the Third Congress of FRELIMO (1977), one of the options of the State was to resort to the recruitment of a large number of technicians abroad" [10]. The idea was to reduce consumption and increase production, which would contribute to improving domestic savings and increasing investments that would in principle reduce Mozambique's external dependence and make the period between 1981-1990 the decade of victory over underdevelopment.

\subsection{Economic Rehabilitation Program (PRE) and Social (PRES)}

Mozambique began its structural adjustment program (Economic Rehabilitation Program) in 1987. This program went through many phases and was applied in times of war, called the Economic and Social Rehabilitation Program (PRES) and submitted to the conceptual evolution programs during this period. As a consequence of the new orientation of the International Financial Institutions, in sense of re- consider Structural Adjustment Programs as poverty reduction programs and, given the very negative performance of the structural adjustment in Mozambique in this regard, the government then decided that there was neither structural adjustment in the country [11].

While it is true that the PRE was able to reverse the "downward trend of the per capita Gross Domestic Product (GDP), particularly since the end of the war in 1992, it is also true that this growth did not break the sustained downward trend of per-capita private consumption" [11].

Poverty has become a matter of particular concern since 1989, in the second year of the PRE and in the context of the Social Dimensions of Adjustment (SDA) initiative, which would subsequently lead to the transformation of the PRE into the PRES. These changes resulted from the adoption in 1984 of the policies of the Bretton Woods Institutions (BWI), namely the World Bank and the International Monetary Fund.

As a consequence, the constitutional amendments of 1990 marked the beginning of a new era in Mozambique characterized by the abandonment of the centrally planned economy for the adoption of decentralization and multipartyism, and a series of changes that manifested because of the PRE [12].

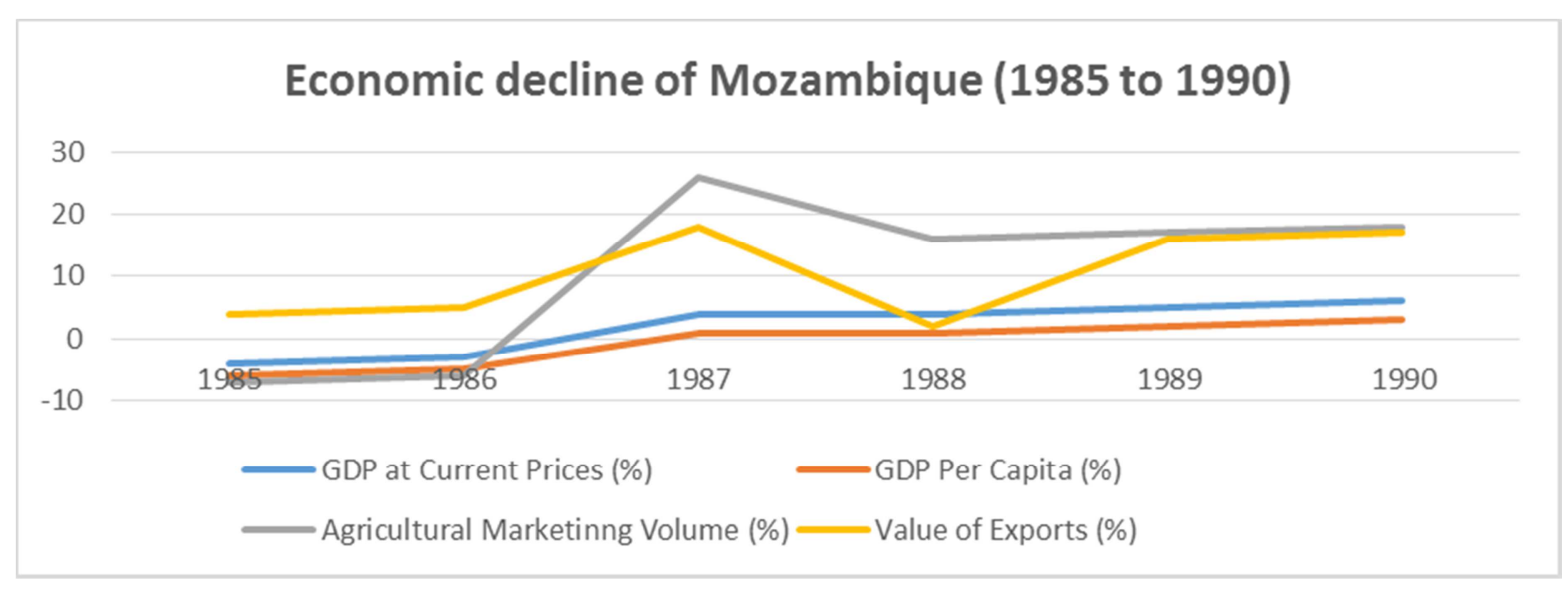

Figure 2. Economic decline of Mozambique (1985 to 1990). 
Table 2. Economic decline of Mozambique (1985 to 1990).

\begin{tabular}{lllll}
\hline Year & GDP at Current Prices (\%) & GDP Per Capita (\%) & Agricultural Marketinng Volume (\%) & Value of Exports (\%) \\
\hline 1985 & -4 & -6 & -7 & 4 \\
1986 & -3 & -5 & -6 & 5 \\
1987 & 4 & 1 & 26 & 18 \\
1988 & 4 & 1 & 16 & 2 \\
1989 & 5 & 2 & 17 & 16 \\
1990 & 6 & 3 & 18 & 17 \\
\hline
\end{tabular}

Source: HERMELE (1990). Mozambique at an economic and political crossroads in the structural adjustment era, Maputo, p.19.

The table and chart above shows the economic decline of Mozambique between 1985 and 1990, which despite having had a considerable decline, these adjustment and economic rehabilitation Plans did not reach their objectives. Therefore, the poorer classes, especially in the cities, felt the cruelest effect of structural adjustment. Public servants saw their wages reduced, reducing their purchasing power, unable to take their children to school and cover hospital expenses; the economy of the country came to depend on foreign capital and corruption, the dilapidation of the public patrimony began to characterize the behavior of the government bureaucracy [13].

However, some benefits were considered, as the Economic and Social Rehabilitation Program reversed the trend of economic decline, in the sense that there was some increase in the flow of food aid and international cooperation, reducing the consequences of famine, country and cushioned collapse of the external sector. There was a debt negotiation in the clubs of Paris and London and the consequent opening to new accessibilities of external financing, which resulted directly in the decision of Mozambique's accession to the IMF and the World Bank and the implementation of the Economic Rehabilitation Program.

In this sense, the markets and stores began to have goods for sale and many products that until then only existed in the parallel market began to be sold; parallel and official market prices have approached, including in the foreign exchange market [14].

According to Abrahamsson \& Nilson, the situation in which the country was in the 1980 s, characterized by a decrease in export revenues and an increase in import requirements, increased the need for external financing, since domestically it was not easy, due to the macroeconomic imbalance resulting from the trade balance negative [15]

In this context, the Mozambican Foreign Policy is gaining new ground. It ceases to focus on the traditional allies of democratic socialist economies to embrace the models of capitalist countries in the West. However, even with this new reality, Mozambique did not break the bilateral cooperation relationship it had with the socialist old friends. However, Mozambique's relationship in the context of foreign policy was fundamentally characterized by bilateral and multilateral cooperation.

According to the World Bank in 1990, at the second meeting of the consultative group in Paris, the Mozambican government presented a broad program that contained the social dimensions of economic rehabilitation of the country, the PRES. In this document, the highlight was the fight against poverty in order to promote the development of the physical structure of rural areas [15].

However, the PRES faced difficulties in its implementation, mainly because of a certain national opposition to the plan, motivated by the party's conception of the plan, as well as the political changes. This was considered as the devaluation of the extremely difficult environment in which the program would be implemented and that security problems would delay the increase in production and erode political support for future reforms in the context of the implementation of the PRES in agricultural, industrial, social, infrastructure, transport, trade sectors, among others.

Parallel to the implementation of the PRES a series of measures were taken to adapt the Constitution of the Republic of Mozambique of 1990 to the adjustment and liberalization of the economy, as well as to multi-party, events that marked a great political transformation (internal and external), economic and social, preceded by economic regression from 1978 to 1990, characterized by the war of 16 years [16].

In the context of the Foreign Policy, Mozambique started to cooperate in its development with the Bretton Woods Institutions, the International Development Agencies, the United Nations (UN), etc.

\subsection{Action Plan for the Reduction of Absolute Poverty 2001-2005 (PARPA-I) and 2006-2009 (PARPA-II)}

Mozambique, after achieving independence, decided to adopt a policy that would contribute to the development of its welfare state, and it was for this purpose that, between 2001 and 2005, it adopted (PARPA-I), which at its core sought to develop the strategy for reduction of poverty.

This plan for its effectiveness had as strategic objective, to substantially reduce absolute poverty levels in Mozambique by taking measures to improve capacities and opportunities for all Mozambicans, particularly the poor. It also pursued the following specific objectives in reducing the incidence of absolute poverty from $70 \%$ (1997) to less than $60 \%$ (2005) and less than $50 \%$ by the end of the first decade of 2000 [17].

Mozambique has made efforts to prioritize areas such as education and health to capitalize on human development. After Mozambique became part of the Economic Restructuring Plan, a major effort was made to regenerate infrastructure inflicted by the war between the government and $\mathrm{RENAMO}^{2}$, and a stabilization and structural adjustment

2 National Resistance of Mozambique, an armed movement founded in the late 1970s by André Machangaissa who opposed the ideals of Frelimo, eventually triggering a 16-year civil war between 1977 and 1992. Nowadays it is the largest opposition party with a seat in parliament. 
process was initiated, aimed to "restore production and improvement of individual incomes, a process of profound reforms towards the launching of an economy provided by private initiative and market forces" [17].

PARPA I had as its main strategy, the maintenance of peace and socio-political stability. With regard to foreign policy as well as cooperation with other countries and peoples, Mozambique adopted the strategy linked to macroeconomic and financial management. This assumption shows that Mozambique has made efforts to create a country that has economic development that contributes to poverty reduction.

These strategies can have a direct impact on the poor. The performance of foreign policy aims to create conditions for the external sector to be one of the instruments to support the rapid and broad growth of the economy. Thus, the exchange rate, the barriers to export and import should be maintained and/or eliminated in a competitive manner, creating services to effectively promote traditional and non-traditional exports.

To the detriment of PARPA I, PARPA II aimed to reduce absolute poverty between 2006 and 2009, with the aim of reducing the incidence of poverty from $54 \%$ in 2003 to $45 \%$ in 2009. In the perspective of this plan, the government should ensure consolidation peace and democracy, social stability and the security of citizens and, as such, had as its priority, guaranteeing individual freedoms as basic conditions for economic growth and absolute poverty reduction.

This program maintained the objectives of to reduce poverty through the redistribution of resources that would also benefit the poorest and most disadvantaged population. However, PARPA II should become more consistent and sustainable, considering the objective of raising the living conditions and well-being of Mozambicans, where selfemployment and savings should play a preponderant role [18].

With regard to macroeconomic management, it should ensure rigorous macroeconomic management by maintaining adequate levels of economic openness, allowing the necessary flows of funds, technology, trade and investment, by maintaining the stability of the financial sector. To this end, actions related to consolidation and strengthening of public finances, monetary management, strengthening banking supervision of insurance activities and of social security system are of relevance [18].

The table and chart below shows clearly the projection of the internal resources generated by the State, which a good part of these is destined for some sectors. Therefore, the government in this period expected that the internal resources thus generated could register a steep growth of $20 \%$ in the period between 2012 to 2014 , caused by the growth of state revenues.

Table 3. Evidence of the projection of domestic resources generated by the State (2011 to 2014).

\begin{tabular}{lllll}
\hline \multirow{2}{*}{ Millions of Mt) } & $\mathbf{2 0 1 1}$ & $\mathbf{2 0 1 1}$ & $\mathbf{2 0 1 2}$ & $\mathbf{2 0 1 3}$ \\
\cline { 2 - 5 } & Projections & & & \\
\hline Total Resources & 132.403 & 141.757 & 168.357 & 168.357 \\
Internal Resources & 74.338 & 81.776 & 93.311 & 107.851 \\
State Revenues & 73.275 & 79.165 & 90.726 & 106.987 \\
Internal Credit & 1.064 & 2.611 & 2.585 & 864 \\
External Resources & 58.065 & 59.981 & 60.495 & 60.506 \\
Donations & 35.769 & 35.285 & 33.696 & 34.061 \\
Credits & 22.297 & 24.697 & 26.799 & 125.742 \\
\hline
\end{tabular}

Source: MPD / MF - QM, REO, C GE and OE with author's adaptations.

\section{Evidence of the projection of domestic resources generated by the State (2011 to 2014)}

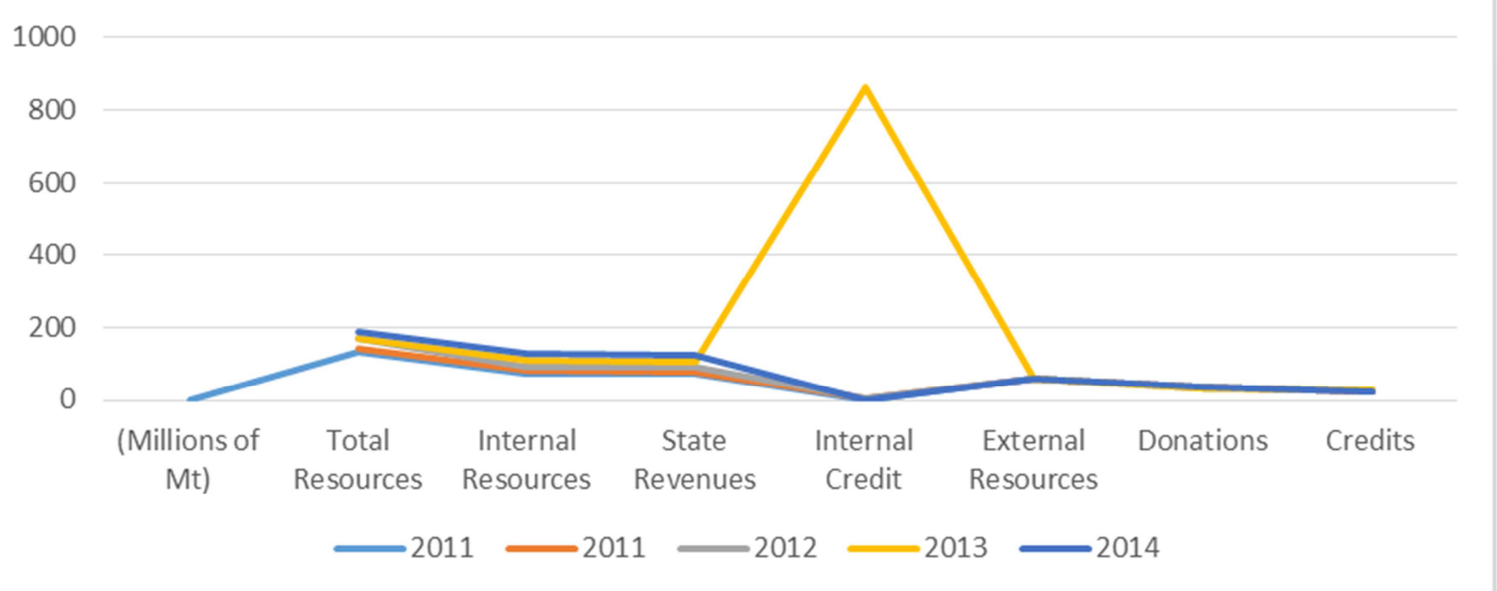

Figure 3. Evidence of the projection of domestic resources generated by the State (2011 to 2014). 
With regard to tax policy, the government should undertake a number of actions to increase administrative efficiency, with the aim of greatly increasing the modernization of domestic resources in proportion to GDP, taking into account the reduction in levels of external dependence.

As for monetary and exchange rate policy, the government should avoid exchange rates, ensuring real interest rates at the appropriate levels for the proper functioning of the economy in order to enable competitiveness, hence the need to maintain low and stable levels, inflation rates, appropriate levels to ensure the country's international commitments [18].

\section{Common Problems with Economic Options in Mozambique}

\subsection{Elements of Continuity and Discontinuity Between PPI and PRE / PRES}

According to Castel-Branco (1998), two dominant global strategies, theoretically opposed to each other, have marked Mozambique's economic path in the last 20 years. The first, known as the Indicative Prospective Plan (PPI), aimed to eliminate the underdevelopment inherited from Portuguese colonialism in just ten years, that is, between 1981 and 1990. It consists of three essential programs - collectivization of the countryside, industrialization and PPI prioritized the rapid growth of material production: a five-year projection of material production was projected for ten years, with an average annual growth rate of $17.5 \%$.

Therefore, PPI implied a passive system of macroeconomic and financial management, a simple bureaucratic instrument of the material plan, in response to the centralized material planning model, since it was believed that deficits then generated would be covered in the future by the effects of rapid product growth and efficiency of enterprises [18].

This component of the PPI isolates the need for external financing, reducing international dependence. Thus, relations with other countries would traditionally focus on sectors that are not necessarily productive.

The second most well-known strategy was the PRE/PRES (Economic and Social Rehabilitation Program), which aimed primarily to repair PPI errors and recovering production and export indexes in 1981. In its view, "the main errors of the previous strategy macroeconomic mismanagement, the distortion of the structure of relative prices in favor of agriculture and exports and the disincentive to the operation of the domestic and foreign private sector" [18].

The program therefore, sought to restore Mozambique's balance of payments and to control inflation through the devaluation of the currency to encourage exports and contain imports, cut public spending and subsidize companies, privatization of state ownership, introduction of the principle of recovery of the costs of providing essential public services, such as health and education and the containment of credit to the economy.

The central argument in these programs was that, the poor macroeconomic management of the PPI period had led the national economy to a serious state of financial and structural imbalance and that only a strong government commitment to reverse past policies and introduce fiscal and monetary policies could restore the health of the economy and the country's international credibility during the gold period of free market advocates. In the new strategy, macroeconomic stabilization was the priority and all others were subordinated to this objective, regardless of the deep structural causes of the economic imbalances in Mozambique.

However, as PRE and PRES were running and promised results were not the pressure of the multilateral agencies WB and IMF - to accelerate the privatization and liberalization of markets for financial and capital goods and services (making this process an end in itself), even when such measures seem irrational and unreasonable in the face of circumstances of the national economy [18].

The two options followed, the PPI and the PRE / PRES, aimed to different objectives: the first was to rapidly expand the capacity and material output of the economy to overcome underdevelopment and the weakness of the socio-economic structure and eliminate poverty. The second sought to restore macroeconomic equilibrium and give more flexibility and efficiency to the economy, correcting the errors generated by the PPI [18].

Even so, these economic strategies shared a series of fundamental problems, the essence of which is their ability to equate and respond to the structural problems of the Mozambican economy. Therefore, they were designed as a response to the need to introduce profound changes, under the pressure of severe structural crises and the dominant donors of each era.

However, they attacked the effects rather than the causes of the problems they intended to respond to, i.e. they did not take into account the causes of economic backwardness and economic instability, or the structural, social, institutional and technological constraints of markets, imposed by that state of the economy. In practice, the PPI and the PRE/PRES were unable to decide what to do, let alone define a transition process that transformed the existing economic structure, agents and institutions.

The PPI "aimed to build a new economic structure, harmonious and developed without worrying much about what would happen to what existed" (Ibid.). PRE/PRES adopted a non-selective attitude towards economic rehabilitation, putting the idea of rehabilitating everything without a clear development strategy until 1989, and imposing severe restrictions on the rehabilitation of anything at a later stage.

\subsection{Elements of Continuity and Discontinuity Between PARPA I and PARPA II}

PARPA II differs from PARAP I because it includes in its 
priorities a greater integration of the national economy and the increase of productivity. Therefore, it demonstrates the development of the base at the district level, the creation of an environment conducive to the growth of the national productive sector, the improvement of the financial system to the flourishing of small and medium enterprises in the formal sector, and the development of both systems of revenue collection budgetary resources.

PARPA II (2006-2009) maintains the priorities in the areas of human capital development in PARPA I (2001-2005) in various areas such as education, health, improved governance, development of basic infrastructure and agriculture, rural development, and improved macroeconomic and financial management.

Paradoxically, the national economy maintains high dependency rates on external capital flows, both official (foreign aid) and private (foreign direct investment and loans in the international banking system). These external capital flows determine the magnitude and patterns of public and private investment, as well as the relationship between public policies and private interests, which is a continuation of this deep dependence, an indicator of the structural fragility of the productive, commercial, and fiscal base of the economy [18].

Mozambique seems to validate the neoliberal models of economic policy advanced by the IMF and the World Bank, according to which monetarist stabilization and economic liberalization promote rapid economic growth and poverty reduction with a macroeconomic sustainable basis.

Two and a half decades after the implementation of stabilization and structural adjustment measures in Mozambique, the stability of monetary indicators, the reduction of poverty and the limited impact of the international crisis remain dependent on these external flows of public capital and private. Without external aid, the growth rates achieved between 1987 and 1989 "would not be sustainable, so the evaluation of industrial performance should focus mainly on the composition of production, its articulations and development of export capacity" [18].

\section{External Economic Relations}

The "external economic relations assume great importance for the correct functioning of the economy" [19]. In view of the economic situation in the 1980 s, considering the global situation at the time, the State prioritized the strict control of the different aspects related to this activity to ensure that it contributes effectively to the development of the national economy.

Until 1985, the main objectives to be achieved in the context of external economic relations were: ensure an increase in foreign exchange earnings by increasing exports not only of products normally exported but also by taking concrete steps to stimulate exports in other products that could potentially be exported; ensure a strict austerity policy on foreign exchange spending; ensure the correct use of available currencies, in accordance with the central objectives defined [19].
At constant prices, the negative external trade balance in 1985 should not be higher than in 1982. Therefore, action should be taken to work because of stable prices, as well as to ensure that the expenses with the importation of equipment and oil and its derivatives to prioritize the remaining imports, especially raw materials and spare parts. The objective was fundamentally to "minimize the worsening of invisible expenses and productive services and maintain the positive balance in existing currencies" [19].

Indebtedness and external dependence result on the low level of domestic savings and its disproportion with gross domestic investment throughout the 1980s and mid-1990s. During this period, Mozambique's external debt increased 120 times, making the country heavily dependent on donations and loans, not always concessional, estimated at the time at about $70 \%$ of GDP [19].

Thus, Mozambique had little choice but to look outside and see how this macroeconomic imbalance would be circumvented. In this way, he made some friends and external enemies.

However, the scenario begins to change in the first multiparty legislature (1995-1999), when the country begins to take steps to reverse the scenario. They played for the country in this context "the political, social stability and peace that resulted from the Rome General Peace Agreement (1992) and the end of the war, as well as macroeconomic and structural reforms, which played an important role for the rapid and steady growth of the economy by encouraging foreign investment" [19]. Although "international trade declined from 278.89 million dollars in 1977 to 153.55 million dollars in 1996" (Idem: 61) in exports for the Organization for Economic Co-operation and Development (OECD) countries.

Official development assistance (ODA) averaged 7\% of GDP for sub-Saharan Africa, excluding South Africa and Nigeria, from 1970 to 1998. In Mozambique aid flows were certainly large, but the level of self-help has been low and affluence has continued year after year, and its support in promoting development is being efficient [19].

The result is that aid in Africa has failed to create conditions for sustained growth and development. There are many reasons why aid was inefficient. One of the problems is that it induces Dutch Disease. Supplemented extensively with the supply of foreign exchange, foreign aid artificially overestimates the real exchange rate by altering the ratio of domestic prices to foreigners in order to reduce competitiveness in the international market [19].

The implication of economic policy is that measures need to be taken to devalue the real exchange rate. Regarding to GDP, "Mozambique received more foreign aid than any other country in the world" [17], during the 1990s. Given the urgency of reconstruction in the transition from war to peace and the low level of real income in Mozambique, aid flows were indispensable. However, from this point on, "the Government initiates actions to reduce dependence on foreign aid in the medium and long term, as a precondition for avoiding marginalization in international trade and 
ensuring its integration into the process of globalization" [19].

The aid, in the form of support to the State Budget and the Projects, constitutes about half of the annual budget in Mozambique, which makes the country one of the most dependent on aid in Africa. The investment seems to be reducing, or else it is of poor quality (i.e. risk). In 1992, when the National Unity Government came to power, official development assistance totaled about \$ 200 million. By 1997, aid from the IMF, World Bank and donor Governments had increased to about $\$ 850$ million.

Although there has been a decline in the level of aid dependency, it remains large. Mozambique was the first country to have access to the original High Indebted Poor Countries (HIPC) initiative in April 1998 and the enhanced HIPC initiative in May 2000. Although "the country's debt has been drastically reduced under the HIPC initiative, it continues large and growing in snowball effect" [20].

Therefore, the aid has conditioned a series of actions aimed to alleviate poverty, on the one hand, but also created conditions for the implementation of programs aimed to combat poverty in various sectors on the other hand, by converting bilateral external debt into development projects, for example.

\section{Conclusion}

The article sought to analyze the various policies and strategies to combat poverty adopted in Mozambique since independence, especially related to the area of Foreign Policy, looking for the elements of continuity and discontinuity.

In spite of these policies and strategies to combat poverty, at their core they were aimed to the same purpose that is the eradication of poverty in Mozambique with a greater focus on maximizing the millennium goals. The PPI, the PRES and PARPA's aimed to eliminate absolute poverty through areas such as education, health, agriculture, rural development, basic infrastructure, good governance, macroeconomic and financial management, considered as priorities in the eradication of absolute poverty in Mozambique, as well as for the link between Mozambique and other countries through cooperation and foreign policy.

In general, the Mozambican political system of that time actually influenced the various political decisions to the point of opting for these plans and strategies for the eradication of poverty that plagued the country, caused by the war and the isolation of the country at world level. Therefore, none of these options understood the limitations and weaknesses of the state and markets, so none of the strategies managed to build the conditions to successfully implement its development lines.

As a result, Mozambique will never significantly reduce poverty if it continues to expect only foreign aid, and with the support of megaprojects and foreign direct investment. By opting for these policies at the time, it was thought that they would be an alternative that could lead the country from the doldrums of underdevelopment, however, these aids and investments, somehow hamper the development of the country.

Economic development options were therefore unable to achieve the goals for which they were adopted, to overcome the constraints of the national economy, and to prevent successive crises of accumulation and development from worsening. However, the entry into operation of the heavy sand and coal explorations contributed to give greater economic expression to Mozambique, opening the way to prosperity and development, which may result from an increase in the internal capacity to save and improve the living conditions of the population, as well as reducing dependence on external resources.

\section{References}

[1] GOVERNMENT OF MOZAMBIQUE (2018). Transforming Our World: The 2030 Agenda for Sustainable Development. Maputo, p. 3; 20.

[2] GOVERNMENT OF MOZAMBIQUE (2015). Five-Year Government Program 2015-2019. Maputo, p. 6.

[3] THE PEOPLE'S REPUBLIC OF MOZAMBIQUE (1977). Fundamental Lines of the Indicative Prospective Plan 19811990. National Press of Mozambique. Maputo, p. 4.

[4] MOSCA, J. (2005). Economy of Mozambique: 20th century. Piaget Institute: Lisbon.

[5] CARVAlHO, A. S. (2008). Entrepreneurs in Times of War: The case of Mozambique, 1974 to 1994, Lusotopie. Port.

[6] THE PEOPLE'S REPUBLIC OF MOZAMBIQUE (1977). Fundamental Lines of the Indicative Prospective Plan 19811990. National Press of Mozambique. Maputo, pp. 5; 25.

[7] MOSCA, J. (2005). Economy of Mozambique: 20th century. Piaget Institute: Lisbon.

[8] WUYS, M. (1991). Mozambique: Economic management and adjustment policies. The IMF and South. The Social Impact of Crisis and Adjustment. Zed Books. London, pp. 8; 9.

[9] FRELIMO PARTY (1982). Economic and Social Directives. Collection 4th Congress. Maputo FRELIMO, p. 45.

[10] THE PEOPLE'S REPUBLIC OF MOZAMBIQUE (1977). Fundamental Lines of the Indicative Prospective Plan 1981-1990. National Press of Mozambique. Maputo, pp. $10 ; 24 ; 27$.

[11] OPPENHEIMER, Jochen (1996). Food Aid, War and Peace Process in Mozambique, 2nd Meeting of Portuguese Language Economists, September, University of Rio de Janeiro, Brazil, pp. 123; 124.

[12] ABRAHAMSSON, H. \& Nilsson, A. (1994). Mozambique in Transition: a study of development history during the 19741992 period. CEEI-ISRI, Padrigu, Maputo, pp. 66-67.

[13] CABINET OF THE ECONOMIC AREAS OF ACCELERATED DEVELOPMENT (GAZEDA). (2009). Investment Legislation: Special Economic Zones and Industrial Free Zones, Maputo. 
[14] MOSCA, J. (2005). Economy of Mozambique: 20th century. Piaget Institute: Lisbon, p. 346.

[15] ABRAHAMSSON, H. \& Nilsson, A. (1994). Mozambique in Transition: a study of development history during the 19741992 period. CEEI-ISRI, Padrigu, Maputo, pp. 49; 19.

[16] ANTÓNIO, E. M. (2008). The Articulation between the Planning and Implementation of Public Policies in Mozambique: the case of PES. Work of the end of the Degree in Public Administration. ISRI, Maputo, p. 16.

[17] GOVERNMENT OF THE REPUBLIC OF MOZAMBIQUE (2001). Action Plan for the Reduction of Absolute Poverty, 2001 - 2005 (PARPA I), Maputo, pp. 1; 2.
[18] GOVERNMENT OF THE REPUBLIC OF MOZAMBIQUE (2006). Action Plan for the Reduction of Absolute Poverty, 2006-2009 (PARPA II), pp. 30; 117; 118; 599; 600; 601; 601; $7 ; 51$.

[19] FRELIMO PARTY (1983). Economic and Social Directives. Collection 4th Congress. Maputo, pp. 57; 58; 58; 55; 36; 131; $132 ; 132 ; 133$.

[20] MARP (2009). Peer review report. Maputo, Republic of Mozambique, p. 87. 